\title{
Rethinking General Education Program for Integrating Local Contexts and English Contents
}

\author{
Puchong Matchimo (Corresponding author) \\ Faculty of Education, Rajabhat Mahasarakham University, Thailand \\ E-mail: puchongmat@gmail.com
}

Samarn Ekkapim

Faculty of Education, Rajabhat Mahasarakham University, Thailand

Surakan Janghan

Faculty of Education, Rajabhat Mahasarakham University, Thailand

Received: October 28, $2021 \quad$ Accepted: November 29, 2021

Published: December 13, 2021

doi:10.5296/jei.v7i2.19127 URL: https://doi.org/10.5296/jei.v7i2.19127

\begin{abstract}
The local and global dimensions are now in balance within the COVID-19 pandemic in all sectors, education needs to be adapted and disrupted for tomorrow. Local contexts in the stream of global movement concerns curriculum and instruction. The local contexts are significant content to promote English by various kinds of contents. This research purposes to study general education program for integrating local contexts and English contents. Target group consisted of teachers who have been taught basic English courses, general education program. The research tools used questionnaire and interviewing form to study the problems and needs for understanding the general education category by integrating content according to local context. As it finding, the local context is the authentic learning experiences that students can learn, they can make a link between local and global dimensions. Conceptual framework is proposed for rethinking genera; education program for integrating local and global English courses, the study needs more discussion how to help students develop learning abilities through the suitable curriculum and instructional practices.
\end{abstract}

Keywords: English, Learning, Local context, Problems 


\section{Introduction}

The lifestyle of each society, which was originally simple to modern life, has its own culture, which is not very relevant to different societies, languages and cultures that are affected by cultural perception. For this reason, it is necessary to change and improve yourself in time for the changes in the global society. To avoid becoming a victim of globalization and to prepare for a sustainable social message while preparing for the right and ongoing changes, international scholars and experts see the country's development in the right direction and remain unique. It is necessary to raise public education to fit the era (Boholano, 2017; Urbani et al., 2017; Anagün, 2018).

As a result of educational importance, English is included in the curriculum at all level, with elementary school students starting from young children to adolescence, also learning English as a foreign language in all countries. While secondary schools can choose from one additional language and choose freely, with the aim of providing students with the ability to use English for a proper and appropriate education in both listening skills. It is not completely separated to local contexts, but teaching English is very important. English is a communicative tool used by humans to study knowledge for a living and to develop themselves to live happily in today's world (Bedir, 2019; Kulachit \& Nuangchalerm, 2021).

The new era of learning needs more knowledge to help students understand in their local contexts. The awareness and importance about community can be used for learning English. Even though it is used worldwide by different situations and also different purposes, the learning should incorporate technology, content, and appropriateness of pedagogy (Prachagool et al., 2016; Nuangchalerm, 2020). It emphasizes reading and comprehension skills in English, which includes sentences and vocabulary, with the attitude of learning basic English to develop and improve the curriculum according to the standards.

In the general education program at Mahachulalongkornrajavidyalaya University focuses on the graduates to have and understand the rules, criteria and use of English, regarding to the use of nouns, the use of tenses, the creation of sentences, and communication purposes. The use of prepositions is capable of using basic skills to listen, speak, read and write in a relative manner (Gurses \& Adiguzel, 2013; Al-Hebaishi, 2017). This research aims to study English reading comprehension programs in general education by integrating local contextual content. The useful of this study will allow educators to redesign and reconsidered how to design curriculum as well as local and global meet education.

\section{Materials and Methods}

This research proposes conceptual framework in the development of an English learning for general education program which the integration local contexts and English contents meet in the learning arena. The comprehension of the framework chooses contents and contexts from the local area where students live. The researchers try to set conceptual framework for preparing the first-year students at Mahachulalongkornrajavidyalaya University in English comprehension course. 


\subsection{Research Tools}

The tools used in this stage of research include questionnaires about problems and needs to develop English reading programs for understanding of general education by integrating local contexts and English contents. Also, interview form is to study the problem conditions and requirements of English reading program for understanding in general education by integrating local contexts and suitable contents.

(1) Questionnaires to study the basics and requirements:

(a) Study documents and theoretical concepts, research related to the development of English course for understanding in general education by integrating local contexts and suitable contents.

(b) Analyze the previous studies to determine the structure and scope of the contents. Feedback and its accordance to the recommendations on the issues to be clearly understood by respondents.

(c) Define the form of the questionnaire by selecting items which appropriate to the subject, including the characteristics of the informants.

(d) Create questions that meet the goals of the research set out according to the structure of the test.

(2) Interview form to study problems and program requirements:

(a) Researchers analyzed the attributes to measure and take effect from the study of the previous studies. Theoretical concepts are defined as a framework for creating interviews.

(b) Structured interview form to conduct interviews by in-depth interview.

(c) Write questions in accordance with the guidelines for creating a clear interview.

4. Prepare the original version of the interview form.

(d) Check interviewing form in acceptable quality, create interview form then updated interview form by 5 experts to check its accuracy.

\subsection{Data Analysis}

Collecting data from questionnaires and interviews, explain the findings by descriptive statistics for data analysis. The conceptual framework was developed and presented by related theory and academic documents.

\section{Result and Discussion}

The result found that teaching in basic English courses in general education subjects was the most problematic in the field of contents. Other problems are moderate, and due to current data conditions, teaching and learning are not responding to the needs of today's English language reading. English reading skills are more problematic than others, making it impossible to read English for comprehension. The researchers then collected data and 


\section{Macrothink}

studied various theoretical concepts related to English learning (Table 1).

Table 1. Related documents and its explanation

\begin{tabular}{|c|c|c|}
\hline No. & Document & Explanation \\
\hline 1 & Caffarella (2013) & $\begin{array}{l}\text { Developing programs to meet the needs of individuals and groups: } \\
\text { 1. To promote the progress and continuous development of individuals. } \\
\text { 2. To help individuals, groups, and communities solve problems that come } \\
\text { through their lives. } \\
\text { 3. To prepare individuals for current and future work. } \\
\text { 4. To help organizations achieve their goals and adapt in time for change. } \\
\text { 5. To allow for consideration by investigating problems and situations in their } \\
\text { communities and society. }\end{array}$ \\
\hline 2 & Roe et al. (2001) & $\begin{array}{l}\text { It is the process of erratic relations in using the meaning of correlation between } \\
\text { the original information in the chapter and the context. }\end{array}$ \\
\hline 3 & Lake (2000) & $\begin{array}{l}\text { Integration is a linkage between knowledge and ideas in different subjects, } \\
\text { which can be a skill integration. This is to achieve holistic learning, covering } \\
\text { Buddhism, skills, and mental disabilities. Integrated learning is learner-centric } \\
\text { that students can apply it in everyday life. }\end{array}$ \\
\hline
\end{tabular}

The results of the program requirements with questionnaires, the basics and requirements in English as shown in Table 2. The empirical data and experts can make a validity to conceptual framework. The experts showed their validation to conceptual framework is at reliable judgement. 
Table 2. Validation to conceptual framework

\begin{tabular}{|c|c|c|c|c|c|c|c|c|c|c|c|c|}
\hline \multirow{2}{*}{ Item } & \multicolumn{10}{|c|}{ Expert judgment } & \multirow{2}{*}{ IOC } & \multirow{2}{*}{ Interpret } \\
\hline & 1 & 2 & 3 & 4 & 5 & 6 & 7 & 8 & 9 & 10 & & \\
\hline 1. Be consistent with the objectives of the course & 1 & 0 & 1 & 0 & 1 & 1 & 1 & 0 & 1 & 1 & 0.7 & Reliable \\
\hline 2. Conforms to purpose & 1 & 1 & 1 & 1 & 0 & 1 & 1 & 1 & 0 & 1 & 0.8 & Reliable \\
\hline 3. Promote student reading skills & 1 & 1 & 0 & 1 & 1 & 1 & 0 & 1 & 0 & 1 & 0.7 & Reliable \\
\hline 4. Comply with measurement and evaluation & 1 & 1 & 1 & 1 & 1 & 1 & 1 & 1 & 1 & 1 & 1 & Reliable \\
\hline 5. Complies with local contextual content integration & 0 & 1 & 1 & 0 & 1 & 1 & 1 & 1 & 1 & 1 & 0.8 & Reliable \\
\hline 6. Students participate in activities & 1 & 1 & 1 & 1 & 1 & 1 & 1 & 1 & 1 & 1 & 1 & Reliable \\
\hline 7. Comply with teaching activities & 1 & 1 & 1 & 1 & 1 & 1 & 1 & 1 & 1 & 1 & 1 & Reliable \\
\hline 8. Students are involved in the use of teaching materials. & 1 & 1 & 1 & 1 & 1 & 1 & 1 & 1 & 1 & 1 & 1 & Reliable \\
\hline 9. The content is suitable for the age and interests of students. & 1 & 0 & 1 & 1 & 0 & 1 & 1 & 1 & 1 & 1 & 0.8 & Reliable \\
\hline $\begin{array}{l}\text { 10. Measurement methods and measurement instruments } \\
\text { are suitable for the behavior they want to measure. }\end{array}$ & 1 & 1 & 1 & 1 & 1 & 1 & 0 & 1 & 0 & 1 & 0.8 & Reliable \\
\hline
\end{tabular}

According to Table 2, the results of the expert assessment by validating conceptual framework English teaching in general education program by integrating local contextual content (Hayikaleng et al., 2016). In the preliminary survey for programming, it helps to promote English reading for greater understanding by integrating local contextual content, which corresponds to Newman (1995), education programs that focuses on changing the behavior of learners such as training programs for industrial workers to improve their skills. Educational programs in which the organization organizes educational activities are to meet the educational needs of employees in the organization such as the program to improve the teaching efficiency of new teachers.

Indeed, educational programs organized according to the student's wishes, with the organization responsible for organizing programs such as study programs abroad of government agencies. Educational programs focused on human resource development in the organization to increase the efficiency and effectiveness of employees in the organization by developing skills and knowledge, leading to the elevation of the standard of work such as training programs for leadership development (Prachagool \& Nuangchalerm, 2021).

General education program is the basic course to promote competency capabilities, so training organizers need to create training kits that enable them to develop basic capabilities after training, such as providing training courses for the arts of after-sales service to customers. Group processes and creating environments are favorable for learning. The experience is an important source of knowledge, such as the peer learning program. 
Educational programs, where educators must study lifestyle, are responsible for encouraging people in the community to ask questions and learn to seek answers for themselves (Zahnd et al., 2017; Chantanee et al., 2018). As program for critical thinking and social action, for example, Project One Tambon, One Products or OTOP etc., accordance to Janobrom (1998), educational programs can be divided into different categories by development programs including community problem solving programs, so they focus on educating them to help solve community problems or individual needs, such as new agricultural theory projects, strong community projects, and human resource development projects for SMEs.

Educational programs include activities that focus on improving a person's abilities for enhancing performance within the organization. Therefore, it is often a program that is organized within institutions or organizations to develop the potential of personnel with clear and specific objectives, such as computer training. The developing learning and teaching in English is now concerning educational technology and using computer programs, including programs that providing information to the public, especially new information, so assessing the success of this program depends on how much information can be reached to the target audience (Nuangchalerm, 2012; Alakrash et al., 2021; Turhan et al., 2021).

The conceptual framework to general education program composed of 8 elements: requirement assessment, set objectives, planning for team settings, Personnel development, evaluation, hands-on procedures, resource management, and environmental assessment. According to Boone (1992), the non-school education development program was presented in the development program in adult education, which consists of 3 main stages: Planning, Design and implementation, and Evaluation.

According to Houle (1996), the human resource development program was presented in the design of education book, which consists of 7 steps as follows: Step 1: Creating a common vision and identifying possible activities, Step 2: Process decisions to apply, Step 3: Objective identification and optimization, Step 4: Designing the right layout for the resource, Step 5: The patterns used are suitable for a large life style, including introducing learners to their lifestyle, Step 6: Bring the plan to the positive impact, and Step 7: Measuring the results and evaluating the effectiveness generated by the development (Caffarella \& O'Donnell, 1987; Wotring, 2021). That is, conceptual framework for rethinking general education program for integrating local contexts and English contents.

\section{Conclusion}

The study employed document analysis to explore the relationship between local and global contexts for designing English course. It is not difficult to integrate local context content due to it is appeared in their daily lives, but it requires the suitable curriculum and instructional practices. The English reading comprehension is necessary for local and global livings, but the new era for learning through authentic contexts may be help students learn English by integrating global contents and local contexts as well as reading comprehension in balance.

\section{References}

Alakrash, H., Edam, B., Bustan, E., Armnazi, M., Enayat, A., \& Bustan, T. (2021). 
Developing English language skills and confidence using local culture-based materials in EFL curriculum. Linguistica Antverpiensia, 548-564.

Al-Hebaishi, S. M. (2017). The effect of peer instruction method on pre-service teachers' conceptual comprehension of methodology course. Journal of Education and Learning, 6(3), 70-82. http://doi.org/10.5539/jel.v6n3p70

Anagün, S. S. (2018). Teachers' perceptions about the relationship between 21 st century skills and managing constructivist learning environments. International Journal of Instruction, 11(4), 825-840. https://doi.org/10.12973/iji.2018.11452a

Bedir, H. (2019). Pre-service ELT teachers' beliefs and perceptions on 21st century learning and innovation skills (4Cs). Journal of Language and Linguistic Studies, 15(1), 231-246. https://doi.org/10.17263/jlls.547718

Boholano, H. (2017). Smart social networking: 21st century teaching and learning skills. Research in Pedagogy, 7(1), 21-29. https://doi.org/10.17810/2015.45

Caffarella, R. S., \& Daffron, S. R. (2013). Planning programs for adult learners: A practical guide. John Wiley \& Sons.

Caffarella, R. S., \& O’Donnell, J. M. (1987). Self-directed adult learning: A critical paradigm revisited. Adult Education Quarterly, 37(4), 199-211. https://doi.org/10.1177/000184818703 7004002

Chantanee, A., Ratanasermpong, M., \& Changcharoen, C. (2018). Scope of curriculum/ program public administration in Thailand. Journal of International Buddhist Studies College, 4(2), 71-84.

Gurses, M. O., \& Adiguzel, O. C. (2013). The effect of strategy instruction based on the cognitive academic language learning approach over reading comprehension and strategy use. Journal of Education and Learning, 2(2), 55-68. https://doi.org/10.5539/jel.v2n2p55

Hayikaleng, N., Nair, S. M., \& Krishnasamy, H. N. (2016). Thai students' motivation on English reading comprehension. International Journal of Education and Research, 4(6), 477-486.

Houle, C. O. (1996). The design of education: Higher and adult education series. Jossey-Bass Inc., Publishers.

Janobrom, S. (1998). Developing programs for adult learners: A guide for non-formal/adult educators, trainers, and program administrator (Department of Non-Formal Education, Faculty of Education, Chulalongkorn University).

Kulachit, N., \& Nuangchalerm, P. (2021). Empirical study on English primary teachers and active learning classroom practice in Thailand. PalArch's Journal of Archaeology of Egypt/Egyptology, 18(4), 2929-2942.

Lake, M. (2001). The use of pedestrian modelling in archaeology, with an example from the study of cultural learning. Environment and Planning B: Planning and Design, 28(3), 
385-403. https://doi.org/10.1068/b2726

Newman, D. R. (1995). A content analysis method to measure critical thinking in face-to-face and computer supported group learning. Interpersonal Computing and Technology Journal, $3(2), 56-77$.

Nuangchalerm, P. (2012). Enhancing pedagogical content knowledge in preservice science teachers. Higher Education Studies, 2(2), 66-71. https://doi.org/10.5539/hes.v2n2p66

Nuangchalerm, P. (2020). TPACK in ASEAN perspectives: Case study on Thai pre-service teacher. International Journal of Evaluation and Research in Education, 9(4), 993-999. https://doi.og/10.11591/ijere.v9i4.20700

Prachagool, V., Nuangchalerm, P., Subramaniam, G., \& Dostal, J. (2016). Pedagogical decision making through the lens of teacher preparation program. Journal for the Education of Gifted Young Scientists, 4(1), 41-52. https://doi.org/10.17478/JEGYS.2016116351

Roe, R. M., Busemeyer, J. R., \& Townsend, J. T. (2001). Multialternative decision field theory: A dynamic connectionist model of decision making. Psychological Review, 108(2), 370. https://doi.org/10.1037/0033-295X.108.2.370

Turhan, G. M., \& Demirci, I. A. (2021). What are the 21 st-century skills for pre-service science and mathematics teachers: Discussion in the context of defined 21 st-century skills, self-skills and education curricula. Journal of Educational Issues, 7(1), 92-112. https://doi.org/10.5296/jei.v7i1.18278

Urbani, J. M., Roshandel, S., Michaels, R., \& Truesdell, E. (2017). Developing and modeling 21st-century skills with preservice teachers. Teacher Education Quarterly, 44(4), 27-50.

Wotring, A. R., Chen, H., \& Fraser, M. (2021). Exploring curriculum alignment through syllabus document analysis: From national language policy to local ELT practice. Iranian Journal of Language Teaching Research, 9(2), 57-72. https://doi.org/10.30466/ijltr. 2021.121045

Zahnd, W. E., Smith, T., Ryherd, S. J., Cleer, M., Rogers, V., \& Steward, D. E. (2017). Implementing a nutrition and physical activity curriculum in Head Start through an academic-community partnership. Journal of School Health, 87(6), 465-473. https://doi.org/ $10.1111 /$ josh. 12515

\section{Copyright Disclaimer}

Copyright for this article is retained by the author(s), with first publication rights granted to the journal.

This is an open-access article distributed under the terms and conditions of the Creative Commons Attribution license (http://creativecommons.org/licenses/by/3.0/). 